\title{
EWA MATKOWSKA
}

ORCID: 0000-0002-9323-6949

Instytut Filologii Germańskiej, Wydział Filologiczny

Uniwersytet Wrocławski

\section{Kampanie i strategie propagandowe towarzyszące budowie muru berlińskiego}

\section{Abstrakt}

Artykuł poświęcony jest kampaniom propagandowym towarzyszącym budowie muru berlińskiego. Policyjnej operacji odcięcia wschodniej części miasta od stref zachodnich towarzyszyły działania agitacyjno-propagandowe poprzedzające operację, trwające w czasie akcji 13 sierpnia 1961 roku oraz działania następcze. W pierwszej części tekstu opisuję kampanię poprzedzającą na podstawie tekstów w dzienniku „Neues Deutschland”, głównym organie prasowym partii SED. Dwa powiązane z sobą tematy są dominujące: „handel żywym towarem” i problem osób regularnie przekraczających granicę sektorów. Stały odpływ ludności (rocznie uciekało z NRD przez Berlin Zachodni od 100 do nawet 300 tysięcy osób) powoduje, że to uciekinierzy staną się głównym tematem kampanii. Kreowana jest znana ze stalinowskiej propagandy historia o działalności zachodnich agentów, którzy rzekomo werbują i sprzedają na Zachód obywateli NRD. Propaganda określa ich mianem „łowców głów” lub „handlarzy ludźmi”. Jako wróg wewnętrzny kreowana jest grupa osób regularnie przekraczających granicę sektorów. To ludzie, którzy mieszkając we wschodnim sektorze, pracowali w zachodnim, co przynosiło realnie wyższe dochody. Manipulując uczuciem zazdrości, propagandyści robią z tej grupy „kozła ofiarnego", obwiniając ją o braki w zaopatrzeniu i nadużycia. Aby położyć im kres - argumentowali propagandyści - należało zamknąć granicę. Im bliżej do samej operacji, tym bardziej agresywna i histeryczna staje się kampania. Kulminuje ona w procesach pokazowych, rozpoczynających się pod koniec lipca 1961 roku, w których zapadają wyroki kary więzienia dla rzekomych „handlarzy ludźmi”. W drugiej części artykułu przechodzę do kampanii następczych, które miały intergrować obywateli w już zamkniętych granicach państwa NRD.

Słowa kluczowe: Mur berliński, propaganda, kampania.

Niniejszy artykuł opiera się na analizie treści oraz analizie ilościowej tekstów prasowych powstałych w obrębie kampanii propagandowej, towarzyszącej budowie muru berlińskiego. Podstawowym wykorzystanym źródłem jest centralny organ prasowy partii SED - dziennik „Neues Deutschland”. Ponadto wykorzystano ma- 
teriały archiwalne resortu agitacji i propagandy SED z wczesnych lat sześćdziesiątych XX wieku, znajdujące się w zasobach Archiwum Federalnego w Berlinie, oraz dostępną literaturę przedmiotu. Przystępując do analizy materiału, autorka zadała sobie następujące pytanie: czy dla czytelnika rozpoznającego manipulacje medialne partyjny organ prasowy mógł pełnić rolę prognostyka przyszłych dramatycznych wydarzeń, w tym przypadku utrzymywanych w najściślejszej tajemnicy przygotowań do budowy muru berlińskiego? Odpowiedź jest, zdaniem autorki, twierdząca. Uważny czytelnik mógł od około połowy czerwca 1961 roku spodziewać się odcięcia wschodniej części miasta.

Szefem sztabu operacji „Róża”, czyli budowy muru berlińskiego, został ówczesny sekretarz KC ds. bezpieczeństwa, późniejszy I Sekretarz KC SED, Erich Honecker. Operacja zaczęła się o godzinie pierwszej w nocy 13 sierpnia 1961 roku wyłączeniem świateł na granicy. O szóstej rano została zakończona. Przejścia między sektorami oraz dworce zostały zamknięte i zabezpieczone zaporami z drutu kolczastego i kozłami hiszpańskimi, ruch kolejki miejskiej - wstrzymany. Miasto w porze urlopowej było opustoszałe, właśnie dlatego zdecydowano się na ten termin. Jak twierdzą historycy, Walter Ulbricht od początku 1961 roku konkretnie przygotowywał zamknięcie granicy. Nikita Chruszczow wyraził zgodę na budowę muru przed moskiewską konferencją państw Układu Warszawskiego, która zaczęła się 3 sierpnia 1961 roku, a 5 sierpnia (w trakcie konferencji) potwierdził tę decyzję — poparli ją przywódcy państw Układu Warszawskiego (Eisenfeld, Engelmann 2001: 41). Rano 13 sierpnia 1961 roku berlińczycy obudzili się w innym mieście. Zaczął się dramat rozdzielonych rodzin i zniweczonych życiowych planów, zaczęły się próby pokonania muru z narażeniem życia.

Pierwszy meldunek o zamknięciu granicy podało radio RIAS o godzinie 3.25. Dwa dni później - po przeczekaniu reakcji RFN - rozpoczęto na wschodzie prace murarskie i dalszą rozbudowę zabezpieczeń. Operacji policyjnej - wojsko było w gotowości, jednak bezpośrednio nie uczestniczyło w akcji, aby nie prowokować odwetu - towarzyszyły działania propagandowe wykorzystujące propagandę bezpośrednią i wszystkie formy propagandy medialnej. Towarzysze SED w okręgach brali udział 13 sierpnia w szkoleniach agitacyjnych, na których podano im argumentację i sposoby wpływania na nastroje społeczne (Eisenfeld, Engelmann 2001: 73). Zgromadzenia i wiece nie były planowane, aby nie przerodziły się w protesty, jak miało to miejsce w czerwcu 1953 roku. W kluczowych punktach miasta (węzły komunikacyjne, dworce, domy towarowe) agitatorzy rozdawali ulotki. Partyjny aparat agitacji i propagandy na jego najwyższych szczeblach w miesiącach poprzedzających operację otrzymywał poufne raporty policji na temat zatrzymań osób udających się do Berlina, a także zbiorcze raporty dziennikarzy z okręgów i powiatów, zaś w miesiącach po akcji - informacje o nastrojach społecznych. Eisenfeld i Engelmann podają: „Od 13 sierpnia do 4 września 1961 roku doszło do ponad 6000 zatrzymań, z czego około 3100 osób zostało aresztowanych” (Eisenfeld, Engelmann 2001: 77). We wrześniu liczba protestów spadła, co historycy tłumaczą zro- 
zumiałą rezygnacją. Bezpośrednią przyczyną, która zmusiła reżim na wschodzie do całkowitego zamknięcia granicy, był stały i masowy odpływ ludności. Rocznie NRD opuszczała ludność odpowiadająca miastu średniej wielkości (od 100 do blisko 300 tysięcy osób). Operacji wzniesienia muru berlińskiego towarzyszyły: kampanie poprzedzające, działania agitacyjne towarzyszące samej budowie muru oraz kampanie następcze, nastawione głównie na integrację obywateli w już ściśle zamkniętych granicach $\mathrm{NRD}^{1}$.

\section{Opis kampanii poprzedzającej na łamach dziennika „Neues Deutschland”: przeciwko „handlarzom żywym towarem” i osobom regularnie przekraczającym granicę sektorów}

Wydział Agitacji przy KC SED koordynował działania propagandowe, których celem było przeciwdziałanie ucieczkom $\mathrm{z}$ republiki ${ }^{2}$. Temat uchodźców pojawiał się regularnie na łamach organu partii SED „Neues Deutschland” (skrót: „ND”) - oczywiście nie w formie rzetelnie przekazywanych wiadomości. Dziennik informował o tysiącach przesiedleńców z Republiki Federalnej Niemiec, którzy rzekomo szukali schronienia w NRD. Losy uchodźców z NRD w RFN przedstawiane były jako pasmo tragicznych w skutkach życiowych porażek.

Analiza treści artykułów w „ND” nie daje jednoznacznej odpowiedzi na pytanie, kiedy zaczęły się działania propagandowe, których celem było bezpośrednie „przygotowanie ludności” do operacji. „Przygotowanie ludności” oznacza w tym kontekście zastraszanie odbiorców, służące zminimalizowaniu oporu i „kosztów użycia siły" (Mueller, Greiner 1969: 17) w trakcie i po operacji. W materiałach resortu agitacji i propagandy - znajdujących się dziś w zasobach Archiwum Federalnego w Berlinie - nie ma wskazówek do intensyfikacji działań, co wynika zapewne z tajności operacji. Pierwszy tekst, w którego tytule pojawia się określenie „łowcy ludzi” — „ND” przedstawiał uchodźców jako ofiary werbunku zachodnioniemieckich władz i agentów — pojawił się na łamach gazety 5 i następnie 14 grudnia 1960 roku.

${ }^{1}$ Artykuł jest dostosowaną do potrzeb niniejszej publikacji i rozszerzoną o nowszą literaturę przedmiotu wersją rozdziału monografii E. Matkowska, Propaganda w NRD. Media i literatura, Wrocław 2012. Tytuły artykułów z „Neues Deutschland” podane zostały w tekście bieżącym, w przekładzie autorki. W bibliografii czytelnik znajdzie wykaz artykułów prasowych z „Neues Deutschland” w języku niemieckim. Monografia zawiera ponadto szczegółowy opis kampanii następczych, prowadzonych już po zamknięciu granicy, które w niniejszym opracowaniu zaledwie wymieniłam. Dalsze omówione w monografii kampanie propagandowe dotyczą: wydarzeń czerwca 1953 roku w NRD, procesu zbrodniarza nazistowskiego Adolfa Eichmanna oraz powstania „Solidarności” w Polsce w 1980 roku.

${ }^{2}$ Przykładowo Materiały stużace do zwalczania ucieczek z Republiki z 5 stycznia 1957 roku podsumowują publikacje i broszury wydawane przez Radę Narodową, Komisję ds. Jedności Niemiec, Ministerstwo Rolnictwa i Leśnictwa; audycje radiowe, programy telewizyjne i filmowe produkowane przez Deutscher Fernsehfunk, Deutschlandsender, Radio DDR, Berliner Rundfunk, DEFA, służące przeciwdziałaniu ucieczkom z NRD. BArch [Bundesarchiv - Archiwum Federalne] DY 30/IV 2/9.02/6. 
Na początku stycznia 1961 dziennik zaczął zamieszczać teksty o treściach bardziej drastycznych: Powiesił się z rozpaczy; Stryczek był jego ostatnim wyjściem; Ostatnia stacja - obóz nędzy. Pierwszy tekst o charakterze apelu ukazał się w maju 1961 roku: List otwarty do uciekiniera $z$ republiki („ND” 18 maja 1961 roku).

Kolejne wyróżniające się artykuły to Uchodźca z republiki ląduje w Legii Cudzoziemskiej („ND” 25 maja 1961 roku), w którym dziennik twierdzi, że uchodźcy są przez Republikę Federalną sprzedawani do Legii Cudzoziemskiej; Powrót z zachodniej strefy. Rozmowy z przesiedleńcami („ND” 28 maja 1961 roku) - jest to wywiad z dobrowolnymi przesiedleńcami ze strefy zachodniej, którzy używają typowych agitacyjnych argumentów: system socjalny w NRD jest lepszy niż w RFN, NRD popiera pokój na świecie, na Zachodzie mieszkania są bardzo drogie, a jedna z bohaterek wywiadu podkreśla, że podoba jej się wschodnioniemiecka telewizja. 30 maja 1961 roku „ND” zamieścił kolejną tragiczną historię uchodźcy Ucieczka z Republiki przypłacona życiem.

Głównym tematem „Neues Deutschland” 1 czerwca 1961 roku była wypowiedź Waltera Ulbrichta na temat traktatu pokojowego. Obok powiązanej z procesem Adolfa Eichmanna kampanii przeciwko sekretarzowi stanu w federalnym Urzędzie Kanclerskim, Hansowi Globkemu, kampania na temat traktatu była prowadzona równolegle do kampanii odnośnie do uchodźców. 3 czerwca 1961 roku „ND” zamieścił artykuł Niebezpieczna poczta z zachodniego Berlina. Tajne służby USA organizuja werbunek obywateli NRD $w$ wielkim stylu. Aktorzy sq znani. W tekście połączone zostały dwa wątki - ucieczka z republiki i rzekoma działalność amerykańskich agentów werbunkowych. Wykreowany przez Stalina obraz „robiącego krecią robotę" imperialistycznego agenta znalazł ponownie zastosowanie. Rzekomy werbunek przez zachodnioniemieckie służby był coraz bardziej eksponowany w kampanii przygotowującej odcięcie wschodniego Berlina: jako motyw przesiedleń z RFN do strefy wschodniej „ND” eksponował niechęć do służby wojskowej w Bundeswerze. W ten sposób temat uchodźców połączono z tematem traktatu pokojowego. W dalszym ciągu „ND” informował o fali uchodźców do NRD: w wydaniu z 12 czerwca 1961 roku znalazł się artykuł Codziennie aż do 139 przesiedleńców. Duży napływ uciekinierów z zachodnich Niemiec.

Za początek prowadzonej od tej pory systematycznie, okresowo nawet codziennie, kampanii należy uznać wypowiedź Waltera Ulbrichta, będącą jednocześnie tytułem artykułu, który ukazał się na łamach „ND” 17 czerwca 1961 roku: Ulbricht: Dla handlarzy żywym towarem nie ma miejsca $w$ Berlinie Zachodnim - Interesy miłujących pokój berlińczyków będa respektowane. „Handel żywym towarem” przez zachodnioniemieckie władze i tajne służby, którego ofiarą masowo padają obywatele NRD, stał się od połowy czerwca dominującym tematem kampanii, której kulminacją były procesy pokazowe przeciwko tak zwanym handlarzom żywym towarem (postępowanie przeciwko Hansowi Adamo i dalszym czterem oskarżonym trwało od 28 lipca do 2 sierpnia 1961 roku). 18 czerwca 1961 roku - następnego dnia po opublikowaniu wypowiedzi Ulbrichta — „ND” zamieścił obszerny artykuł Handel 
ludźmi wczoraj i dziś. Nowoczesny kapitalizm jest systemem sprzedajności autorstwa Haralda Wessela, w którym wprowadzono główne argumenty kampanii przeciwko „handlarzom żywym towarem” i „łowcom głów”. 21 czerwca 1961 roku „ND” zamieścił artykuł Zachodni Berlin - centrum handlu żywym towarem. Były pracownik Urzędu Ochrony Konstytucji ujawnia zbrodnie kliki z miasta frontowego. Heinz Falk „ujawnił” w nim, że w interesie Zachodu leży utrzymanie Berlina Zachodniego jako „bagna agentów” i „miasta frontowego zimnej wojny”. 24 czerwca 1961 roku głos na łamach „ND” zabrał sekretarz ds. agitacji i propagandy, Albert Norden, w tekście W pore przeciać lont zachodniego Berlina. 25 czerwca 1961 roku „ND” zamieścił tekst Organizatorzy handlu żywym towarem pod pregierzem.

1 lipca władze wprowadziły pierwsze restrykcje natury administracyjnej przeciwko ludziom regularnie przekraczającym granicę sektorów (niem. Grenzgänger). Były to w większości osoby mieszkające we wschodnim Berlinie i pracujące w sektorach zachodnich. Od 1 lipca osoby te mogły kupować towary wartościowe (samochód, telewizor, pralka itp.) tylko za okazaniem zaświadczenia o stosunku pracy na terenie NRD. Ze względu na korzystny kurs wymiany ludzie przekraczający granicę sektorów zarabiali średnio więcej niż zatrudnieni w sektorze wschodnim. Manipulując uczuciem zazdrości, propagandyści zdecydowali się z tej właśnie grupy zrobić kozła ofiarnego: zamknięcie granicy miało położyć kres ich uprzywilejowaniu i rzekomym nadużyciom. Wrogiem zewnętrznym niezmiennie pozostawała RFN, na wroga wewnętrznego zaś intensywnie kreowano osoby regularnie przekraczające granicę sektorów. Grupę tę uczyniono także odpowiedzialną za braki w zaopatrzeniu.

W lipcu „ND” zamieścił kolejne artykuły o charakterze apelu: 12 lipca 1961 ukazał się tekst Zamknać drogę handlarzom żywym towarem. Robotnicy VEB Industriebau popieraja działania przeciwko przekraczającym granicę. Forum w Funkversuchswerk Adlershof. W relacji cytowany jest robotnik, który twierdzi: „Czytałem w gazecie o osobach regularnie przekraczających granicę, że nie mogą już tak wygodnie robić zakupów. Był już najwyższy czas, czemu czekaliśmy tak długo?”. 19 lipca 1961 roku „ND” opublikował artykuł Bonn płaci od głowy za żywy towar. Adenauer forsuje polityke ultrareakcjonistów, a dzień później Miasto frontowe zachodni Berlin - miejsce przeładunku w handlu żywym towarem. Wstrzasajaca relacja o zatwardziałym, który dostał się w sieci handlarzy żywym towarem. Na tej samej stronie „ND” zamieścił kolejny tekst, z którego czytelnik może się dowiedzieć, że handlarze żywym towarem dostają nawet do 1000 marek zachodnich „od głowy”. Również ten tekst ma charakter apelu, podtytuł brzmi: Młodzież NRD oskarża. Całkowicie nielogiczna i nieprawdopodobna argumentacja ilustrowana jest historiami z życia codziennego, które są rażąco przerysowane.

22 lipca 1961 roku „ND” zamieścił artykuł Zachodnioniemieckie koncerny finansują handel żywym towarem. Czytelnik mógł się dowiedzieć, że za handlem ludźmi stoi między innymi koncern IG-Farben, który płaci premie aż do 3000 marek zachodnich „od głowy”, a rząd w Bonn wspiera te działania za pomocą ulg podatkowych. Więcej nawet, w zachodnioniemieckich zakładach powstają specjalne ko- 
misje zajmujące się werbunkiem sił fachowych z NRD i zasiadają w nich ci sami ludzie, którzy w czasach nazistowskich zajmowali się sprowadzaniem do III Rzeszy robotników przymusowych ze wschodu. Źródłem tych informacji jest program telewizyjny „Treffpunkt Berlin”, w którym wystąpił szef Wydziału Agitacji KC SED, Horst Sindermann. W tym samym wydaniu gazety na stronie 6 znalazł się artykuł Przekraczajacy granice wyciagają konsekwencje. Jest to relacja z urzędów meldunkowych we wschodnim Berlinie, do których zgłaszają się osoby regularnie przekraczające granicę, prosząc o pracę w NRD: „Jeżeli tu mieszkam, muszę tu pracować”. Jednocześnie „ND” podaje przykład przyłapanego na gorącym uczynku małżeństwa „przekraczającego granicę”, które próbowało przewieźć mięso i wędliny na Zachód, za co zostało skazane na trzymiesięczną karę więzienia. Dziennik przedstawił zatem pozytywne efekty wychowawcze działań magistratu przeciwko osobom przekraczającym granicę, jednocześnie grożąc sankcjami w razie niestosowania się do obowiązujących przepisów. „ND” zamieścił w tym wydaniu także artykuł Ofiary handlu żywym towarem wracaja. Zbiegli z agencji szpiegowskich i domów uciech. Według „ND” zachodnioniemieccy i amerykańscy agenci werbują obywateli NRD, aby pozyskać od nich interesujące dla służb wywiadowczych informacje, „postnazistowskie" koncerny kupują wykwalifikowaną siłę roboczą, szkodząc w ten sposób młodemu socjalistycznemu państwu, ale to jeszcze nie koniec zbrodniczej działalności. Zachód zajmuje się stręczycielstwem - kobiety z NRD trafiają do domów publicznych w RFN. W artykule zrozpaczony ojciec zwraca się do Ulbrichta z prośbą o przyjęcie jego rodziny z powrotem do NRD: na skutek strasznych warunków w obozie dla uchodźców zmarło jego dziecko, rodzinie odmówiono pomocy medycznej. Na stronie 3 czytamy Brudny interes handlu żywym towarem. $Z$ dyskusji $z$ Günterem Wirthem, członkiem CDU.

23 lipca 1961 roku na stronie 1 i 2 znalazł się tekst Ostatnia stacja cmentarz o strasznym losie uciekiniera na Zachodzie, a dzień później „ND” zamieścił kilka artykułów na temat uchodźców: NRD - nasza prawdziwa ojczyzna. Byli obywatele RFN, którzy przybyli do NRD, potępiaja boński handel żywym towarem; Handlarz żywym towarem Lemmer pod pregierzem; Brak przekraczajacych granice. 25 lipca 1961 roku „ND” opublikował artykuł Łowcy głów z USA ida na polowanie. Amerykańskie tajne służby utrzymuja centrale werbunkowe w zachodnim Berlinie. W spisku $z$ Brandtem i Lemmerem. Z tekstu czytelnik dowiaduje się, że amerykańskie tajne służby utrzymują w zachodnim Berlinie „wiele filii do werbunku obywateli NRD”, zwerbowani mieszkają w ośrodkach dla bezdomnych. Bonn zwiększyło finansowanie „zachodnioberlińskich ośrodków łowców rolników”. W zachodnim Berlinie działają więc już nie tylko centrale werbunkowe, mieszczą się tam także filie, wyspecjalizowane na konkretne grupy zawodowe. 26 lipca 1961 roku „ND” donosił, że urzędnik zachodnioberlińskiego senatu zajmował się handlem ludźmi. 27 lipca 1961 roku w kolumnie Berlińczyk sięgną po pióro zamieszczano teksty, w których wyrażano poparcie dla działań rządu przeciwko osobom regularnie przekraczającym granicę. Na przykład Luiza M. wyraziła swoje niezadowolenie, twierdząc, „że 
ludzie, którzy są wierni naszemu państwu, dłużej czekają na telewizor niż przekraczający granicę". Müller i Greiner są zdania, że pojawienie się kilku listów do redakcji w następujących po sobie dniach powinno być traktowane jako wyznacznik bliskości operacji.

28 lipca 1961 roku „ND” zamieścił cztery teksty w ramach kampanii - interesujące jest to, że w trzecim tekście powołano się na „Frankfurter Allgemeine Zeitung" krytykującą warunki w obozach dla przesiedleńców. Mimo stałych ataków na prasę z RFN bywa ona przywoływana $\mathrm{w}$ celu uwiarygodnienia własnej pozycji. Tę samą sprzeczność można zauważyć przy propagandowym wykorzystaniu wypowiedzi zachodnich polityków, jak na przykład wypowiedzi senatora Fulbrighta w dalszej części kampanii. Zabieg ten był jak najbardziej zamierzony, co potwierdza notatka Alberta Nordena skierowana do Horsta Sindermanna w sprawie procesu nazistowskiego w RFN w 1962 roku: „Tylko w drugim rzędzie interesują nas w tym kontekście głosy bratniej prasy komunistycznej na Zachodzie, ale przede wszystkim prasa burżuazyjno-socjaldemokratyczna. Co napisała w Belgii katolicka gazeta »Het Volk« i burżuazyjna gazeta »La Wallonie« oraz w jaki sposób pisała szwedzka burżuazyjna prasa [...]" (BArch, DY 30/IV 2/9.02/7, k. 128-129).

29 lipca 1961 roku kampania osiągnęła szczyt w formie relacji z pokazowego procesu zorganizowanego wyłącznie w celach propagandowych. Kozłem ofiarnym kampanii został architekt Hans Adamo, zatrudniony w VEB Farbenfabrik Wollen, co umożliwiało połączenie tego procesu $\mathrm{z}$ wątkiem IG-Farben (w propagandzie NRD IG-Farben była synonimem mordu w interesie kapitalistycznych koncernów). Na ławie oskarżonych zasiedli Hans Adamo, Günter Bartel, Monika Rinke, Rolf Schumann i Ludwig Gleich. Zostali oni oskarżeni o handel żywym towarem i przekazywanie Zachodowi tajnych informacji. Na drugiej stronie znalazł się ciąg dalszy tej relacji z dużym zdjęciem zasiadających na ławie oskarżonych. Z komentarza czytelnik dowiaduje się, że w żywy towar zaopatrują się w NRD między innymi koncerny zbrojeniowe i takie firmy, jak IG-Farben, ZAISS-Opton z Heidenheim, koncern Springera. 30 lipca 1961 roku „ND” na stronie 1 zamieścił artykuł Przeszkodzić łowcom ludzi w ich rzemiośle - czytamy w nim, że zwerbowani w NRD młodzi ludzie umieszczani są w koszarach NATO, gdzie przygotowywana jest wojna przeciwko NRD, młode kobiety „lądują w burdelu”. Połączone zostają wątki traktatu pokojowego i „handlu żywym towarem”: kto współpracuje z handlarzami ludzi (czyli uchodźcy, osoby regularnie przekraczające granicę i im pomagające) „dopuszcza się zdrady na sprawie pokoju”. Tego samego dnia „ND” wprowadził do kampanii wątek najbardziej drastyczny: ofiarami rozlicznych przestępstw Zachodu stały się dzieci. Propagandyści nie wahali się użyć znanego $\mathrm{z}$ antysemickiej propagandy oskarżenia o uprowadzanie dzieci - rzekomymi sprawcami są według „ND” "handlarze żywym towarem": Porwanie dziecka, żeby szantażować rodziców. Kidnaperzy porywaja trzyletniego Petera Bluhme z Dissen do zachodniego Berlina. Porywaczem jest „znana ze stronienia od pracy” babcia dziecka, ojciec dziecka to „członek sił zbrojnych NRD”. Motywem babci było uzyskanie „szczególnie wysokiej premii od handlarzy 
żywym towarem”. Wraz z wprowadzeniem do kampanii wątku przestępstw, których ofiarami padają dzieci, wkroczyła ona w ostatnią fazę: od 1 do 13 sierpnia ukazało się w „ND” w sumie 11 tekstów poświęconych porwaniom lub porzuceniu dzieci na skutek działalności Zachodu lub ucieczki rodziców. Prawie cały numer ND z 31 lipca 1961 roku został poświęcony projektowi praw człowieka KPZR.

1 sierpnia 1961 roku władze wprowadziły dalsze administracyjne restrykcje wobec osób regularnie przekraczających granicę sektorów: musiały się one rejestrować w urzędach meldunkowych, opłacać czynsz, wodę i prąd w markach zachodnich; przepis ten dotyczył również członków ich rodzin.

W numerze z 1 sierpnia "ND” informował, że oficjalne zachodnioniemieckie placówki wspierają „łowców głów”. 2 sierpnia zamieszczono tekst o charakterze apelu: Założono Komitet Zakładowy „Walka z handlem żywym towarem”. Robotnicy $B G W$ : „Nie damy sobie w kasze dmuchać”. W artykule przedstawiona została historia Horsta Jankego, pracownika fabryki żarówek, który najpierw w roli przekraczającego granicę sektorów, później uchodźcy, działał na zlecenie zachodnioniemieckiej firmy OSRAM i namawiał kolegów do ucieczki. „Dzięki czujności robotników został ujęty”. Proces — zgodnie z relacją „ND” — odbył się w zakładzie pracy, robotnicy żądali podjęcia ostrzejszych środków przeciwko przekraczającym granicę: „Powinni płacić za czynsz, gaz i światło w tej walucie, w której zarabiają”. W tym samym wydaniu „ND” poinformował, że nadburmistrz wschodniego Berlina, Friedrich Ebert, zwrócił się do senatu i do burmistrza zachodniej części miasta, Willy’ego Brandta, z żądaniem „rozwiązania kwestii przekraczających granicę”. Na stronie 1 „ND” podał, że oskarżony o handel żywym towarem Hans Adamo został skazany na 15 lat więzienia. „Przed południem czwartego dnia procesu odczytano w sądzie obszerną "naukową analizę", opracowaną przez kolegium ekspertów na temat handlu żywym towarem, organizowanego przez Bonn". Na stronie 3 kontynuowano historię porwanego chłopca $\mathrm{z}$ dużym zdjęciem dziecka. Na stronie 7 dziennik zamieścił informację o wypowiedzi amerykańskiego senatora Fulbrighta: „Zdenerwowanie handlarzy żywym towarem z powodu propozycji kompromisu Fulbrighta”; następnego dnia wypowiedź amerykańskiego senatora komentowana była na pierwszej stronie gazety: Amerykański senator przeciwko handlowi żywym towarem. Fulbright: „Wschodni Niemcy maja prawo zamknać swoje granice”. Wrzask wściekłości w Bonn. Na stronie drugiej „ND” przedstawił historię ilustrującą brutalność zachodnioberlińskiej policji. Szantażowała ona Aloisa Schustera, który domagał się powrotu rodziny do NRD: „Zostanie pan w zachodnim Berlinie albo nigdy nie zobaczy swojej rodziny”. Na tej samej stronie „ND” informował, że CIA kształci handlarzy żywym towarem. Na stronie 7 dziennik pisał o powstaniu kolejnego zakładowego komitetu przeciwko handlowi żywym towarem. 4 sierpnia 1961 roku „ND” na pierwszej stronie informował o poparciu ludności dla propozycji traktatu pokojowego: Brygada młodzieżowa berlińskich zakładów elektrycznych im J.W. Stalina $w$ interesie całego narodu: walka o pokój i podwyższenie norm. Kolejny tekst o pozbawionych skrupułów działaniach uchodźców to historia szesnastolatki przetrzymywanej przez ro- 
dziców w RFN oraz budująca historia o przekreśleniu planów „łowców głów” przez czujnych obywateli. Dopiero 5 sierpnia - najwyraźniej obawiając się reakcji ludności - dziennik poruszył temat obowiązujących od 1 sierpnia przepisów o rejestracji osób stale przekraczających granicę, zamieszczając głosy poparcia płynące od ludności i wyrazy wdzięczności dla magistratu: „Nareszcie! — relacjonował „ND” — „Rano opuszczali miasto, aby pracować dla wrogów państwa robotników i chłopów, wieczorem pasożytowali przy stole socjalizmu". Na stronie drugiej znalazła się informacja o kolejnym procesie: Bruno Kilat, kierownik produkcji zachodnioberlińskiego przedsiębiorstwa, został skazany na 2,5 roku więzienia. W toku postępowania dowiedziono, że „przekraczający granicę produkują materiały wojenne”.

Od 3 do 5 sierpnia trwała w Moskwie konferencja pierwszych sekretarzy partii komunistycznych państw Układu Warszawskiego, podczas której Ulbricht uzyskał poparcie dla budowy muru. „ND” informował, że „normalizacja sytuacji w zachodnim Berlinie nie może być już dłużej odwlekana”. 6 sierpnia 1961 roku na stronie 1 ukazała się kolejna notatka o porwaniu dziecka, artykuł o rodzicach, którzy sprzedają się handlarzom ludźmi i porzucają własne dzieci. Szczególną rolę należy przypisać pojawieniu się w „ND” relacji ze spotkania sekretarza ds. agitacji i propagandy, Alberta Nordena, z obywatelami. Czuwający nad całością działań mediów szefowie partyjnych struktur propagandy i agitacji, Albert Norden i Horst Sindermann, przeważnie pozostawali w cieniu, w decydujących momentach zabierali jednak głos osobiście. $\mathrm{Na}$ spotkaniu z Nordenem poruszono kwestię osób przekraczających granicę. Robotnicy pytali sekretarza, dlaczego tak późno wprowadzono restrykcje przeciwko osobom regularnie przekraczającym granicę: "Już całe lata nas to złości”. Norden odpowiedział, że proszono Willy’ego Brandta o zniesienie „oszukańczego kursu”, ale nie zgodził się, co „zmusiło nas do użycia innych środków”. 7 sierpnia 1961 roku „ND” kontynuował historię porwania chłopca, Petera Bluhme, i donosił o kolejnych dowodach świadczących o tym, że przekraczający granicę produkowali materiały wojenne. W wydaniu „ND” z 8 sierpnia 1961 roku zamieszczono głosy poparcia dla działań magistratu w formie listów od czytelników - pojawiła się informacja o podjęciu pracy w NRD przez 228 osób pracujących dotąd w zachodnim Berlinie, a także artykuł o międzynarodowym zasięgu zachodnioniemieckiego handlu żywym towarem: hiszpańscy i greccy pracownicy w RFN są, według relacji „ND”, ofiarami handlu żywym towarem. 9 sierpnia 1961 roku „ND” opisał kolejną historię porwania dziecka oraz zamieścił ciąg dalszy historii porwanego chłopca, Petera Bluhme. Oba teksty mają charakter apelu: „Sylvia ma niezwłocznie zostać oddana rodzicom!”; „Peter Bluhme musi zostać uwolniony!”. Czytelnicy dowiadują się, że „miliony matek żądają tego razem z rodzicami”. W tym samym numerze „ND” poinformował o kolejnych 165 „krwawych sędziach” (sędziach z nazistowską przeszłością) w RFN. 10 sierpnia 1961 roku „ND” pisał o działaniach zakładowych komitetów przeciwko handlowi żywym towarem oraz zamieścił list inteligencji z miasta Schwerin, która potępiła handel żywym towarem. $\mathrm{Na}$ stronie 8 dziennik opublikował relację z rejestracji osób przekraczających granicę 
Godzina decyzji. Rejestracja osób przekraczających granicę zaczęła się. Stolica ma pracę dla każdego obywatela.

11 sierpnia 1961 roku na stronie pierwszej znalazła się kontynuacja „afery Bluhme” z żądaniem powrotu porwanego chłopca; pod hasłem „Koniec z brudnym handlem żywym towarem przez bońskich militarystów" na stronie 5 ND zamieścił szereg krótkich artykułów poświęconych osobom przekraczającym granicę. 12 sierpnia dziennik relacjonował posiedzenie Izby Ludowej. Przewodniczący Rady Państwa, Willi Stoph, powiedział w swoim przemówieniu, że walka z handlem żywym towarem jest częścią działań związanych z traktatem pokojowym, zażądał zwrócenia porwanych dzieci i zapewnił: „Będziemy potrafili bronić spokojnego życia naszej ludności”. Na stronie 3, w artykule Wola ludu na wokandzie „ND” relacjonował kolejny, trzeci już, pokazowy proces przez Sądem Najwyższym (na ławie oskarżonych znaleźli się: Helene Vogt, Werner Herde, Margarethe Pauels, Manfred Wagner). Strona czwarta została poświęcona przemówieniu Williego Stopha i apelowi robotników do osób przekraczających granicę: Kto je przy naszym stole... Mieszkańcy Pankow mówia przekraczającym granice swoje zdanie. Komitet przeciwko handlowi żywym towarem odwiedził biuro rejestracyjne. 13 sierpnia 1961 roku — granice były już zamknięte - „ND” zamieścił na pierwszej stronie obwieszczenie Rady Ministrów NRD i oświadczenie rządów państw Układu Warszawskiego. Na stronie 2 „ND” informował o sensacyjnych zeznaniach w toczącym się procesie przed Sądem Najwyższym, które odsłaniają metody handlarzy żywym towarem. Pracownikom ministerstwa bezpieczeństwa udało się przeniknąć do amerykańskich tajnych służb i zdemaskować metody handlu ludźmi. Na stronie 7 moralnego rozliczenia z handlarzami żywym towarem dokonał „ekspert” dr Harald Wessel. Wydanie zamykało poparcie chilijskiego poety, Pablo Nerudy, dla NRD.

\section{Podsumowanie kampanii prowadzonej na łamach „Neues Deutschland” — wnioski}

Podsumowując liczbę tekstów na temat uchodźców i osób regularnie przekraczających granice sektorów Berlina (niem. Grenzgänger), które ukazały się od początku 1961 roku na łamach „Neues Deutschland”, otrzymujemy następujące dane miesięczne: styczeń - 22, luty - 16, marzec - 16, kwiecień - 12, maj - 15, czerwiec - 18, lipiec - 54, w okresie od 1 do 13 sierpnia - 104 teksty. Analiza treści i liczby publikowanych artykułów ukazuje, że od połowy czerwca działania propagandowe wyraźnie się nasilają: wprowadzony zostaje temat „handlu żywym towarem”. Od lipca osoby regularnie przekraczające granicę sektorów Berlina są na łamach „ND” wyraźnie kryminalizowane. Jest to ta grupa w społeczeństwie, która została wykreowana na wewnętrznego wroga. Propagandyści manipulują uczuciem zazdrości - dzięki pracy w zachodnich sektorach osoby regularnie przekraczające granicę osiągały wyższe realne dochody. Wrogiem zewnętrznym wciąż pozostaje Republika 
Federalna Niemiec. Teksty o charakterze apelu oraz „listy do redakcji”, w których czytelnicy domagają się rozwiązania problemu rzekomego uprzywilejowania osób stale przekraczających granicę, powinny być interpretowane jako wyznacznik bliskości operacji. Zanim kampania osiągnęła punkt kulminacyjny — medialne relacje z pokazowych procesów - wprowadzony został najdrastyczniejszy z wątków: uciekinierzy i osoby przekraczające granicę oskarżone zostały o przestępstwa, których ofiarami padają dzieci. Pokazowe procesy przeciwko rzekomym „handlarzom żywym towarem" rozpoczęły się pod koniec lipca 1961 roku, zapadły w nich surowe wyroki. Argumentacja używana w kampanii przeczy wszelkiej logice i doświadczeniu, jest niewiarygodna, a jej ton staje się coraz bardziej agresywny, cyniczny i histeryczny. Celem działań mediów jest sianie niepewności i zastraszenie służące zmniejszeniu oporu podczas samej akcji policyjnej, która miała miejsce 13 sierpnia 1961 roku. Podsumowując całość działań mediów, można powiedzieć, że przygotowania zaczęły się w połowie czerwca, a z końcem lipca uważny obserwator wydarzeń mógł spodziewać się odcięcia wschodniego Berlina.

\section{Kampanie następcze}

Kampanie następcze realizowały kilka różnych celów: demonstrowały siłę władzy komunistycznej, inscenizowały poparcie narodu dla działań władz (kampania wykorzystująca Grupy Bojowe Klasy Robotniczej), dyscyplinowały (kryminalizacja ofiar muru i heroizacja sprawców, Kampania przeciwko wrogim nadawcom) oraz integrowały społeczeństwo w nowych warunkach (kampania werbunkowa komunistycznej młodzieżówki FDJ Ojczyzna wzywa - brońcie naszej socjalistycznej republiki, kampania Kobieta, pokój i socjalizm). Po budowie muru partia SED utrzymała agresywny i ofensywny charakter propagandy i agitacji - do grudnia 1961 roku wszystkie wymienione kampanie były w toku.

Jako dominującą strategię rozpoznać można ofensywność działań agitacyjno-propagandowych. Bardzo ważny kontekst działań propagandowych stanowiło wprowadzenie obowiązkowej służby wojskowej w styczniu 1962 roku. Kampanie Ojczyzna wzywa - brońcie naszej socjalistycznej Republiki i Kobieta, pokój i socjalizm muszą być postrzegane na tym tle. Nadal prowadzono kampanię propagującą traktat pokojowy, kampanię związaną z procesem Eichmanna i kampanię przeciwko tak zwanym krwawym sędziom.

Rok po budowie muru władze SED rozpoczęły zakrojoną na szeroką skalę ofensywną kampanię przeciwko zachodniemu Berlinowi i RFN, której przewodnie hasło brzmiało: „Era Adenauera dobiega końca”.

Resort agitacji i propagandy zbierał, choć nie w sposób systematyczny, opinie na temat skuteczności podejmowanych działań. Na ich podstawie można odnieść wrażenie, że skuteczność działań nie była wysoka. Materiały potwierdzają na przykład zdecydowanie negatywny odbiór Kampanii przeciwko wrogim nadawcom, podczas 
której młodzieżówka FDJ łamała bądź przekierowywała na wschód anteny radiowe na dachach domów (Matkowska 2012: 178). Należy jednak zaznaczyć, że to nie cel perswazyjny był dominujący. Prawdziwym celem kampanii poprzedzających budowę muru berlińskiego wydaje się zastraszenie społeczeństwa, tak aby zaplanowana, bezprecedensowa operacja przebiegła bez zakłóceń. Agresywny i histeryczny ton w mediach powodował, że zdecydowani na ucieczkę zbiegli przed akcją, niezdecydowani mieli pewność, że przeciwnik jest niebezpieczny, nieobliczalny, a skutki oporu mogą być bardzo dotkliwe. Część społeczeństwa natomiast można było przekonać do nawet najbardziej absurdalnych argumentów. Bilans z perspektywy nadawców propagandy był zatem pozytywny.

\section{Bibliografia}

Wykaz artykułów dziennika „Neues Deutschland”, źródło: Staatsbibliothek Berlin

8346 kamen in die DDR, „ND” 1960, 7 marca.

13000 Übersiedler in drei Monaten, „ND” 1960, 8 kwietnia.

Es ist eine Tragödie - Ins Nichts gelockt, „ND” 1960, 22 kwietnia.

Mehr als 3000 Übersiedler im April, „ND” 1960, 23 kwietnia.

„Ich war bloß ein Arbeitsvieh”, „ND” 1960, 30 kwietnia.

Ständig 700 Übersiedler, „ND” 1960, 29 października.

700 Umsiedler leben in Stalinstadt, „ND” 1960, 3 listopada.

Den Menschenjägern auf der Spur, „ND” 1960, 5 grudnia.

Aus Verzweiflung erhängt, „ND” 1961, 5 stycznia.

Der Strick war sein letzter Ausweg, „ND” 1961, 8 stycznia.

Letzte Station: Elendslager, „ND” 1961, 11 stycznia.

Offener Brief an einen Republikflüchtigen, „ND” 1961, 18 maja.

Republikflüchtiger landet in der Fremdenlegion, „ND” 1961, 25 maja.

Rückkehr aus der Westzone. Mit der Wahrheit „vorbelastet”. Gespräche mit Übersiedlern aus der Westzone im neuen Aufnahmeheim Schmalkaden, „ND” 1961, 28 maja.

Republikflucht mit dem Leben bezahlt, „ND” 1961, 30 maja.

Walter Ulbricht über Friedensvertrag und Westberlin-Frage. Interview des Neuen Deutschland mit dem Vorsitzenden des Staatsrates des Deutschen Demokratischen Republik und Ersten Sekretär des ZK der Sozialistischen Einheitspartei Deutschlands, „ND” 1961, 1 czerwca.

Gefährliche Post aus Westberlin. USA-Geheimdienst organisiert Abwerbung von DDR-Bürgern im großen Stil. Die Akteure sind bekannt, „ND” 1961, 3 czerwca.

Flucht vor Wehrpflicht, „ND” 1961, 7 czerwca.

Der Bundeswehr entkommen, „ND” 1961, 14 czerwca.

Täglich bis zu 139 Übersiedler. Stärkerer Strom der Flüchtlinge aus Westdeutschland, „ND” 1961, 12 czerwca. Ulbricht: Für Menschenhändler ist kein Platz in Westberlin - Die Interessen der friedliebenden Bevölkerung werden respektiert, „ND” 1961, 17 czerwca.

Wessel Harald, Menschenhandel gestern und heute. Der moderne Kapitalismus ist ein System der Käuflichkeit, „ND” 1961, 18 czerwca.

Westberlin - Zentrum für Menschenhandel. Ehemaliger Mitarbeiter des Amtes für Verfassungsschutz enthüllt Verbrechen der Frontstadtqlique, „ND” 1961, 21 czerwca.

Zündschnur Westberlin rechtzeitig durchschneiden, „ND” 1961, 25 czerwca. 
Organisatoren des Menschenhandels werden angeprangert, „ND” 1961, 25 czerwca.

Menschenhändlern Weg verlegen. Arbeiter des VEB Industriebau stimmen Maßnahmen gegen Grenzgänger zu. Forum im Funkversuchswerk Adlershof, „ND” 1961, 12 lipca.

Frontstadt Westberlin-Umschlagplatz für Menschenhandel. Erschütternder Bericht über einen Unbelehrbaren, der in die Fänge der Menschenjäger geriet, „ND” 1961, 20 lipca.

Kopfprämien bis zu 1000 Westmark. Die DDR-Jugendliche klagen an/Neues Übersiedlerheim an Dresden, „ND” 1961, 20 lipca.

Westdeutsche Konzerne finanzieren Menschenhandel, „ND” 1961, 21 lipca.

Grenzgänger ziehen Konsequenzen, „ND” 1961, 21 lipca.

Opfer des Menschenhandels kehren zurück. Den Spionageagenturen und Animierhäusern entronnen, „ND” 1961, 22 lipca.

USA-Kopfjäger gehen auf Beute aus. Amerikanischer Geheimdienst unterhält Abwerbezentralen in Westberlin/Mit Brandt und Lemmer unter einer Decke, „ND” 1961, 25 lipca.

Senatsbeamter als Kopfjäger. Neue Enthüllungen über Menschenhandelszentralen in Westberlin, „ND” 1961, 26 lipca.

„Grenzfrage: Wohin gehörst du?”, „ND” 1961, 27 lipca.

Gehlen und Dulles wühlen in Westberlin. Wie Kopfjäger ihre Beute behandeln, „ND” 1961, 28 lipca.

Terroranschlag gegen Arbeiterklasse, „ND” 1961, 28 lipca.

Frankfurter Allgemeine gibt zu: katastrophale Zustände in Lagern, „ND” 1961, 28 lipca.

Menschenhandel im Konzernauftrag. Prozeß gegen 5 Kopfjäger der Bonner Ultras vor dem Obersten Gericht, „ND” 1961, 29 lipca.

Menschenjägern das Handwerk legen!, „ND” 1961, 30 lipca.

Kinderraub, um Eltern zu erpressen. Kidnapper entführen den dreijährigen Peter Bluhme aus Dissen nach Westberlin, „ND” 1961, 30 lipca.

Peter muss befreit werden, „ND” 1961, 1 sierpnia.

Die Kopfjäger erpressen rücksichtslos jeden, der die DDR verrät, „ND” 1961, 1 sierpnia.

Betriebskomitee "Kampf gegen Menschenhandel” gegründet. BGW-Arbeiter: „Wir lassen uns nicht in die Suppe spucken.”, „ND” 1961, 2 sierpnia.

Zuchthaus gegen Menschenhandel beantragt. 15 Jahre für den Kopfïger Adamo, „ND” 1961, 2 sierpnia.

Der kleine Peter und das Lindbergh-Gesetz, „ND” 1961, 2 sierpnia.

Aufregung bei Menschenhändlern über Kompromissvorschlag von Fullbright, „ND” 1961, 2 sierpnia.

Frau und Kind nach Westberlin verschleppt, „ND” 1961, 3 sierpnia.

USA-Senator gegen Menschenhandel. Fullbright: „Die Ostdeutschen haben das Recht, ihre Grenzen zu schließen”. Wutgeschrei in Bonn, „ND” 1961, 3 sierpnia.

CIA bildet Menschenhändler aus. Erfurter Staatsanwalt Rudert: „Gerichtsakten klagen Westberlin an.”, „ND” 1961, 3 sierpnia.

Kampf gegen Menschenhandel. Betriebskomitee auch im Motorenwerk Johannisthal gegründet, „ND” 1961, 3 sierpnia.

16-jähriges Mädchen schrie ihren Eltern ins Gesicht: „Ihr seid Verräter am Sozialismus”, „ND” 1961, 4 sierpnia.

Kopfjäger blitzen ab, „ND” 1961, 4 sierpnia.

Grenzgänger werden registriert und zahlen Miete, Strom, Gas, Wasser in Westgeld. Beschluß des Magistrats verwirklicht. Vorschläge der Bevölkerung, „ND” 1961, 5 sierpnia.

Prozess gegen Menschenhändler beweist: Grenzgänger produzieren Kriegsmaterial, „ND” 1961, 5 sierpnia.

Abgeblitzt. Arbeiter verjagen DDR-Feinde. Faschistische Elemente über Staatsgrenze vertrieben. Bad Salzungen, Hermann und Willi Fink. Zurückführen zum Kapitalismus, „ND” 1961, 5 sierpnia.

Kindesraub im Kreis Neustrelitz. Gemeines Verbrechen der modernen Menschenhändler, „ND” 1961, 6 sierpnia.

Verstoßene Kinder klagen an , „ND” 1961, 6 sierpnia.

Die eigenen Kinder hilflos ausgesetzt, „ND” 1961, 6 sierpnia. 
Vom Licht in Lampen und Köpfen. Gespräche Albert Nordens mit Arbeitern und Ingenieuren des Berliner Glühlampenwerkes, „ND” 1961, 6 sierpnia.

Erpressen lassen wir uns nicht! Bei den Eltern von Peter Bluhme, „ND” 1961, 7 sierpnia.

Leser zu Maßnahmen des Magistrats, „ND” 1961, 8 sierpnia.

228 Grenzgänger kehren zurück, „ND” 1961, 8 sierpnia.

Menschenhandel mit Ausländern, „ND” 1961, 8 sierpnia.

Kindesräuber versuchten Spuren zu verwischen. Quadenschönfelder Einwohner verlangen: Sylvia Heintz soll unverzüglich ihren Eltern zurückgegeben werden, „ND” 1961, 9 sierpnia.

Peter muss befreit werden!', „ND” 1961, 9 sierpnia.

Betriebskomitee „Kampf gegen Menschenhandel in Aktion, „ND” 1961, 10 sierpnia.

Unser Vaterland ist die DDR. Brief an Walter Ulbricht: Angehörige der Intelligenz aus Schwerin verurteilen Menschenhandel, „ND” 1961, 10 sierpnia.

Stunde der Entscheidung. Registrierung der Grenzgänger hat begonnen. Die Hauptstadt hat für alle Bürger Arbeit, „ND” 1961, 10 sierpnia.

19. Tagung der Volkskammer der DDR, Die Zeit für entschlossene Maßnahmen ist da, „ND” 1961, 12 sierpnia.

Volkes Wille auf der Tagesordnung, „ND” 1961, 12 sierpnia.

Wer an unserem Tisch isst ... Pankower sagen Grenzgänger ihre Meinung/Komitee gegen Menschenhandel kam in die Registrierstelle, „ND” 1961, 12 sierpnia.

Wessel Harald, Wer im Sich lässt seinesgleichen, lässt ja nur sich selbst im Stich. Eine moralische Abrechnung mit Menschenhandel und Menschenhändlern unserer Tage, „ND” 1961, 13 sierpnia.

\section{Literatura przedmiotu}

Amos H. (2003): Politik und Organisation der SED-Zentrale 1949-1963, Münster.

Bussemer T. (2008): Propaganda. Konzepte und Theorien, Wiesbaden.

Dobek-Ostrowska B. (2006): Komunikowanie polityczne i publiczne, Warszawa.

Eisenfeld B., Engelmann R. (2001): 13.8.1961: Mauerbau. Fluchtbewegung und Machtsicherung, Bremen.

Engels J.F. (2004): Helden an der Mauer. Die propagandistische Aufarbeitung der Republikfluchten in der deutschen Presse, Münster.

Gibas M. (2000): Propaganda in der DDR, Erfurt.

Holzweißig G. (1983): Massenmedien in der DDR, Berlin.

Ideologiczna wspótpraca. Władze wobec środowisk opiniotwórczych w PRL i NRD (2016): red. S. Ligarski, K. Ruchniewicz, D. Wojtaszyn, Wrocław.

Lapp P.J. (2013): Grenzregime der DDR. Helios, Aachen.

Materialien zur Bekämpfung der Republikflucht. Im letzten Halbjahr bzw. in Vorbereitung, 5 I 1957, Bestand SED ZK Abt. Agitation, BArch, DY 30/IV 2/9.02/6.

Matkowska E. (2012): Propaganda w NRD. Media i literatura, Wrocław.

Mueller E.F., Greiner P. (1969): Mauerbau und „Neues Deutschland”, Bielefeld.

Taylor F. (2009): Die Mauer. 13. August 1961 bis 9. November 1989, Berlin.

Wojtaszyn D. (2007): Obraz Polski i Polaków w prasie i literaturze Niemieckiej Republiki Demokratycznej $w$ okresie powstania Solidarności i stanu wojennego wojennego, Wrocław. 


\section{Propaganda campaigns and strategies accompanying the construction of the Berlin Wall}

\section{Summary}

The article deals with propaganda campaigns connected with the construction of the Berlin Wall. Propaganda activities assisted the police operations which were aimed at the separation of the east sector from the west sectors of Berlin. These activities took place before, during and after the operation 13, August 1961. In the first part of the paper I describe the prior campaign on the basis of daily newspaper "Neues Deutschland”, the main press organ of the political party SED. The two dominating topics are related: „the human trafficking” and the people regularly crossing the sector border. Refugees became the main topic of the campaign due to the constant mass outflow of people (from 100 to even 300 thousand people fled through West Berlin annually). The fake story, common in the soviet Stalin era, tells about western agents recruiting and trading citizens of the GDR to the West. They were denominated by the propaganda as "head hunters” or "human traffickers". The people regularly crossing the sector border became the inner enemy. They lived in the eastern sector and worked in the western sectors which resulted in higher revenue. By manipulating the aroused feeling of jealousy the propagandists turn the group into a scapegoat. They accuse them of lack of merchandise and of offences. To put an end to these activities the border had to be closed. The closer to the day of the operation, the more aggressive and hysteric becomes the campaign. The culminant events are the "show trials" at the end of July 1961 during which the assumed ", human traffickers" are sentenced to prison. The second part of the article deals with post campaigns which aimed at integration of the citizens within the borders of the DDR.

Keywords: the Berlin Wall, propaganda, campaign. 